\title{
Effect of Conservation Agricultural Practices on Candidate Herbicides Persistence under Maize-Sunflower System in Tropical Indian Conditions
}

\author{
P. Janaki ${ }^{1,2 *}$ and P. Murali Arthanari ${ }^{1}$ \\ ${ }^{1}$ Department of Agronomy, Tamil Nadu Agricultural University, Coimbatore-641 003, \\ Tamil Nadu, India \\ ${ }^{2}$ Department of Soil Science and Agricultural Chemistry, Anbil Dharmalingam Agricultural \\ College and Research Institute, Tamil Nadu Agricultural University, \\ Tiruchirapalli- 620027, India
}

\begin{tabular}{l} 
K e y w o r d s \\
Conservation \\
agriculture, Crop \\
residue, Dissipation, \\
Atrazine, \\
Pendimethalin, \\
Zero tillage \\
Article Info \\
$\begin{array}{l}\text { Accepted: } \\
\text { 14 June } 2020 \\
\text { Available Online: } \\
\text { 10 July } 2020\end{array}$ \\
\hline
\end{tabular}

\section{A B S T R A C T}

Conservation agriculture (CA), an input saving concept has gaining momentum in India to address the labor shortage, soil health and sustaining crop productivity. However the adoption of CA practices has issues of poor weed control, increased herbicides application etc. due to loss of efficacy. This may also alter the persistence and dissipation behavior of herbicides in soil. Hence field experiments were conducted at Tamil Nadu Agricultural University, Coimbatore during 2014-16 to study the influence of different combinations of CA practices and weed management methods on the persistence of atrazine and pendimethalin applied to maize-sunflower cropping system. The experiments were laid out in strip plot design with three replications. Main plot consisted of 1 conventional practice, 3 combinations of conventional and zero tillage practices with and without crop residue incorporation and one complete zero tillage with residues across maize and sunflower growing seasons. Sub plots consisted of three weed management methods viz., PE herbicides (Atrazine $0.5 \mathrm{~kg} / \mathrm{ha}$ for maize and pendimethalin $1.0 \mathrm{~kg} / \mathrm{ha}$ for sunflower), PE herbicides (Atrazine $0.5 \mathrm{~kg} / \mathrm{ha}$ for maize and pendimethalin $1.0 \mathrm{~kg} / \mathrm{ha}$ for sunflower) plus hand weeding on 45 days after sowing and control. Results showed that the initial residue of pendimethalin in sunflower field soil was 0.423 to $0.482 \mathrm{mg} / \mathrm{kg}$ and atrazine in maize field soil was 0.239 to $0.316 \mathrm{mg} / \mathrm{kg}$ respectively. Dissipation of both the herbicides followed first order reaction kinetics with the half life of 14.9-19.6 and 14.7-19.7 days, respectively for pendimethalin and atrazine. Dissipation of pendimethalin was slow under CA practices and vice versa for atrazine. Herbicides nature, crop residues type and crops grown have effect on the herbicides degradation through herbicide interceptions. Weather variables like rainfall, temperature and sunshine hrs also has interactive influence on herbicides dissipation along with CA practices. Results suggest that the influence of CA practices should be studied under long run to understand the changes in the efficacy and behaviour of herbicides in soil. 


\section{Introduction}

Conservation agriculture is a recent resource saving concept introduced worldwide aiming to sustain the crop production and accomplish better profit while conserving the soil environment (FAO, 2010). This practice aims to reduce tillage, increase the vegetative cover of soil and growing crops in rotation. In recent years, the conservation agriculture has gaining momentum in India to address the labor shortage, soil erosion, poor soil organic matter build-up and unsterilized production. However the management of weeds in CA system set the farmers into trouble and directs to spray herbicides for controlling the weeds. Reducing tillage intensity generally tends to increase the weeds population in topsoil and is often associated with an increase in herbicide use (Alletto et al., 2010). Hence the farmers normally forced to spray both pre and post emergent herbicides at more frequency and at higher doses in CA system. Loss in efficacy of pre emergence (PE) herbicides is the major concern in high residue conservation tillage systems. Reduced efficiency of herbicides under CA due to weed seed bank development and herbicides interception by the retained residue was also reported by the researchers (Banks and Robinson 1982; Potter et al., 2006).

The effect of surface crop residues on interception, subsequent wash-off, and movement of herbicides through soil are major concerns associated with no-tillage practice. The mulch intercepts excess surface chemical spray which would otherwise be sorbed and dispersed in the soil upon application. In addition, there is an added benefit of continued slow-release and increased efficiency of these herbicides leading to a potential reduction in post emergence chemical inputs as gradual desorption from the straw mulch may provide extended control of second flushes of weed emergence and growth (Dao, 1991).
Atrazine (2-chloro-4-ethylamino-6-isopropylamino-1,3,5-triazine) and pendimethalin $(\mathrm{N}-$ (1-ethylpropyl)-2,6-dinitro-3,4-xylidine) are the candidate herbicides applied as pre and post emergence to manage weeds in field crops. While atrazine is used in Indian agriculture since late 1990s for the pre- and post emergent control of weeds in crops such as maize, sorghum etc., pendimethalin is applied as pre and early-post emergence to manage weeds in annual pulses and oilseed crops. Atrazine is a selective systemic herbicide metabolized by maize after absorption and translocation into the plant system. However the pendimethalin is not metabolized by the plant and create either susceptibility or resistant to crops. The degradation half life of atrazine and pendimethalin in soil varied from 4-57 weeks and 43 -62 days in soil depending on various environmental factors like $\mathrm{pH}$, moisture content, temperature and microbial activity (Vencill, 2002; Janaki et al., 2012 a,b). The influence of soil moisture and temperature on pendimethalin degradation was quicker under anaerobic condition than aerobic condition (Vencill, 2002).

Adoption of CA system would distress the fate of the applied pesticides through altering the soil physical, chemical and biological properties particularly under long term adoption. Influence of conservation tillage practices on the in situ herbicide dynamics in the agricultural soil was not studied in India. Some work has been done at laboratory level under controlled conditions. The modification of the soil environment and microbial populations by reduced tillage and/or cover crops can affect herbicide fate (Levanon et al., 1994; Locke and Zablotowicz 2003) as most herbicide transformations in soil are mediated by microbial metabolism. Anil Kumar and Swaranjit Singh (2013) reported that the organic matter content of soil has significant influence on the adsorption of simazine and atrazine in Punjab soils. Soil 
with high organic matter content has better herbicide's adsorption ability.

Maize and sunflower are the crops highly suited to CA system in the deep clayey to sandy clay loam soils of Tamil Nadu, India. Both atrazine and pendimethalin are applied frequently in maize and sunflower crops, respectively in Tamil Nadu as they are cheap and gave efficient control of weeds. Though these molecules are efficient in managing weeds, they perform differently under CA system due to their interception by the crop residues and lack of timely release of active ingredients for weed control. Hence the present study was carried out to assess the influence of conservation agricultural practices on the persistence and dissipation of candidate herbicides under maize-sunflower cropping system in tropical conditions of Tamil Nadu, India.

\section{Materials and Methods}

The field experiment was initiated during Kharif 2015 at the eastern farm of TNAU, Coimbatore with Maize-Sunflower cropping system. The experimental farm is located in the Western Agroclimatic Zone of Tamil $\mathrm{Nadu}$ at $11^{\circ} \mathrm{N}$ latitude and $77^{\circ} \mathrm{E}$ longitude with an altitude of $426.7 \mathrm{~m}$ above MSL. Experiment was laid out in strip plot design with TNAU Maize Hybrid COHM 6 and TNAU Sunflower Hybrid CO 2 as test varieties. The details of the treatments imposed for the study is given in Table 1 . Every year the maize and sunflower was sown during kharif and rabi seasons, respectively. Plot size of $5.5 \times 15 \mathrm{~m}$ was maintained for each treatment and the bunds were kept undisturbed as permanent one. Sowing of both the crops was made at spacing of $60 \times 30$ $\mathrm{cm}$. For imposing the conventional tillage, the country plough was used before sowing while in the zero tillage plots, the sowing was taken at optimum moisture using the hand pressure.
The residue of the previous crop was retained to impose the residue mulching in the required treatment plot. Accordingly harvest of the previous crop was done to retain the maximum residue in the plot to account 2.5 to 3.0 tonnes of residue per hectare. Herbicides were sprayed as pre emergent on $3^{\text {rd }}$ day after sowing the crop using knapsack sprayer fitted with flat-fan nozzle and $450 \mathrm{~L} / \mathrm{ha}$ water as spray volume. The soil samples were collected from the experimental field on 0,15 and 45 days after herbicide spray and at crop harvest. Collected soil samples were homogenized, air dried and processed and stored for analysis. Plant samples were collected at harvest, processed and sub sampled for residue analysis. Maize and sunflower harvests were done on 105 and 95 days, respectively. The experimental field soil was clayey in texture with $\mathrm{pH} 8.31$, EC 0.83 $\mathrm{dS} \mathrm{m}^{-1}$ and $0.48 \%$ organic carbon.

\section{Residue extraction and determination}

The valid homogenized representative sample from each replication of each treatment was subjected to herbicides residue extraction using a mixture of methanol: water (7:3) and methanol alone for atrazine and pendimethalin, respectively. The extraction and cleanup of the compounds residue was done as detailed by Janaki et al., (2012a, b). The final residue of both the herbicide was reconstituted in acetonitrile for determination in HPLC.

The certified reference standards of both atrazine and pendimethalin of $>96 \%$ purity were dissolved in methanol to obtain 1000 $\mathrm{mg} / \mathrm{L}$ stock solution. From the main stock standard, the working standards of 0.001 to $5.0 \mathrm{mg} / \mathrm{L}$ were prepared in acetonitrile for carrying out the calibration and recovery studies to find out the limit of detection (LOD) and limit of quantification (LOQ). 
Herbicides residue was analyzed by an Agilent HPLC equipped with photo diode array detector and auto sampler. The separation of compounds was achieved by an Agilent Eclipse XDB-C18 (5 $\mu \mathrm{m}, 4.6$ x 150 $\mathrm{mm}$ ) column by injecting $10 \mu \mathrm{L}$ sample and using acetonitrile and water $(7: 3, \mathrm{v} / \mathrm{v}$ for atrazine and $8: 2 \mathrm{v} / \mathrm{v}$ for pendimethalin) as mobile phase with a flow rate of $0.5-0.8 \mathrm{~mL}$ $\mathrm{min}^{-1}$. The detection of the compounds was made at a wavelength of 221 and $230 \mathrm{~nm}$ for atrazine and pendimethain, respectively. Chromatogram was acquired using Ez Chrome software. The residue was calculated comparing the peak areas of samples with its standards run under same optimized HPLC conditions.

\section{Data analysis}

The dissipation rate and determination coefficient for herbicides residue were analyzed using first order kinetics: $\ln \mathrm{Ct}=\ln$ $\mathrm{C} 0-\mathrm{kt}$, Where $\mathrm{Ct}(\mu \mathrm{g} / \mathrm{g})$ stand for herbicide concentration at time $\mathrm{t}$ (days), $\mathrm{C} 0(\mu \mathrm{g} / \mathrm{g})$ stands for initial concentration, $\mathrm{k}$ was the first-order rate constant. The time taken by the initial residue to dissipate its $50 \%\left(\mathrm{DT}_{50}\right)$ was calculated as: $\mathrm{DT}_{50}=\ln 2 \mathrm{k}$. The Pearson correlation analysis was carried out in MS excel 2010 to find the linearity of relationship between herbicides concentration and time and to calculate the level of significance.

\section{Results and Discussion}

Under the optimized conditions of HPLC, atrazine and pendimethalin were resolved at 4.20 and 7.39 minutes respectively (Fig 1). The limit of detection (LOD) and limit of quantification (LOQ) for both the molecules were found to be 0.01 and $0.05 \mathrm{mg} / \mathrm{kg}$ in all matrices. The calibration curve was found to be linear from 0.05 to $2.0 \mu \mathrm{g} \mathrm{mL}^{-1}$ for both the compounds $\left(\mathrm{r}^{2}=0.969 * *\right.$ for pendimethalin; $\mathrm{r}^{2}=0.989 * *$ for atrazine $)$.

\section{Initial residue deposition in soil}

Soil samples collected from kharif 2015 in maize field at the time of crop harvest were analyzed for the atrazine residue and were found below the detection limit of $0.01 \mathrm{mg} / \mathrm{kg}$ under all treatments. Since kharif 2015 is the first year of trial, persistence study was not performed. The residues of pendimethalin during rabi 15-16 with sunflower crop and atrazine during kharif 16 with maize crop was analyzed at different periods viz., 0, 15, 45 days after herbicide application and at harvest and the results obtained are given in Table 1 and 2. The initial residue of pendimethalin in sunflower field and atrazine maize field was ranges from 0.423 to 0.482 and 0.239 to 0.316 $\mathrm{mg} / \mathrm{kg}$, respectively. The residues of both the compounds decreased with time (Fig. 2) and were below the detectable limit at the time of harvest (95 days in maize and 105 days for sunflower). Though the influence of conservation agricultural practices and weed management methods on initial residue deposition was meager, their influence on the persistence of these molecules was observed in soil at later period. Similar results were reported by Janaki et al., (2019) that the detection of atrazine residues up to 10 days under zero tillage practice and 30 days under conventional tillage practices.

Initial deposition of pendimethalin residue itself is low in all the plots and could be attributed to the leaching losses as influenced by the high rainfall $(84 \mathrm{~mm})$ received on $1^{\text {st }}$ day after its application and also through entire first week of its spray (Fig 3). High temperature on the day of application might also be credited to the less initial residue by the volatilization loss of this herbicide. These results showed that apart from tillage and residue cover, the herbicides persistence in soil was also influenced by the climatic factors such as temperature, light intensity and rainfall prevailed during the crop growth 
period (Janaki et al., 2016). Locke and Bryson (1997) reported that the intensity and timing of rainfall are important considerations in determining the effects of residue management on herbicide loss in surface runoff and leaching. Runoff and leaching loss is high especially if the rain fall occurs immediately after herbicide application when the herbicide concentration is high in soil. This was also happened in the present study.

\section{Dissipation half life of herbicides in soil}

The dissipation of both the molecules followed first order reaction kinetics $\left(\mathrm{R}^{2}>\right.$ 0.90) irrespective of tillage practices under both the weed control methods (Fig 4 and 5) and the parameters of dissipation are given in Table 3. The dissipation rate constant of pendimethalin and atrazine varied respectively, from 0.035 to 0.046 and 0.036 to 0.047 days $^{-1}$ and the half life varied from 14.9-19.6 and 14.7-19.7 days in the present study. Similar half lives of 21.54 days for atrazine and 14.63 days for pendimethalin was reported in maize and soybean cultivated soils, respectively (Janaki et al., 2009; Janaki et al., 2012a, b). A significant variability $(\mathrm{p}<0.05)$ in $\mathrm{DT}_{50}$ was observed among the conservation agricultural practices and weed management methods.

Pendimethalin half life was found to be higher under CA than conventional practices and could be attributed to the slow degradation of pendimethalin under conservation practices due to slow release into soil solution for chemical and microbial degradation from the crop residues intercepted portion (Janaki et al., 2016). The atrazine half life was observed to be 2-3 days higher under conventional practices than CA system under atrazine alone plots and no difference was seen under atrazine plus hand weeding method (Table 3). This could be ascribed to the nature of maize crop residue present in the sunflower field soil which interact with the herbicide residue and converted it into non extractable bound residues when compared to sunflower residue in maize field which received atrazine. Khalil (2018) also reported that the barley and wheat residues intercepted more herbicide than an equivalent mass of canola, chickpea or lupin residue, and attributed to increased ground cover by cereal residues.

\section{Pendimethalin dissipation rate of in soil}

The dissipation rate of pendimethalin herbicide was found to be higher under conventional practices (CT-CT) and was followed by the CT-ZT than the conservation agricultural (CA) practices viz., $\mathrm{ZT}+\mathrm{R}-\mathrm{ZT}$, $\mathrm{ZT}-\mathrm{ZT}+\mathrm{R}$ and $\mathrm{ZT}+\mathrm{R}-\mathrm{ZT}+\mathrm{R}$ (Fig 4). The pendimethalin dissipation values on day 15 in sunflower grown soil under CT-CT, CT-ZT, $\mathrm{ZT}+\mathrm{R}-\mathrm{ZT}, \quad \mathrm{ZT}-\mathrm{ZT}+\mathrm{R}$ and $\mathrm{ZT}+\mathrm{R}-\mathrm{ZT}+\mathrm{R}$ practices were observed to be $71,65,63,58$ and 58 percent for pendimethalin alone at 1.0 $\mathrm{kg} / \mathrm{ha}$ and $61,60,50,57$ and 55 percent, respectively for pendimethalin at $1.0 \mathrm{~kg} / \mathrm{ha}+$ HW at 45 DAS imposed treatments. Comparing the weed management methods, the dissipation rate was higher in pendimethalin alone @ $1.0 \mathrm{~kg} / \mathrm{ha}$ applied plot irrespective of type of tillage practices. This could be attributed to the utilization of herbicides by the existing weed seed bank in the soil due to lack of hand weeding during previous maize crop.

The higher rate of pendimethalin dissipation under conventional practices could be attributed to the easy volatilization loss and fast chemical degradation facilitated by the lack of crop residues to absorb herbicide. The environmental conditions prevailed during the early crop growing period (Fig. 3) like high temperature and wet soil might also augmented the volatilization loss of pesticides by keeping the active ingredients in soil solution (Alletto et al., 2009). Further the 
tilling of soil every season in conventional tillage field might fasten the chemical and biological degradation of pendimethalin residues in soil compared to conventional practice. Higher sorption of fluometuron by soils with no-tillage and crop cover than the conventional tillage practice was also reported by Gaston et al., (2001). Under CA practices, the slow dissipation of pendimethalin was observed and could be attributed to temporary immobilization through its retention on crop residues. The absorbed residue would be released slowly to soil and so the dissipation rate was low. The interception of chemical spray by the previous year's crop residues and the reduction of soil - applied herbicide efficacy were also reported by Banks and Robinson, (1982) and Ghadiri et al., (1984). Dao (1995) observed two- to fivefold increase in metribuzin retention in the near-surface zone of no-till soils and relates with the elevated organic carbon content due to straw addition. Nitrogen availability in soil also affects the herbicides degradation in soil through changing $\mathrm{C}: \mathrm{N}$ and microbial community in soil (Nalini et al., 2013). Influence of integration of organic $\mathrm{N}$ inputs on enhancing the degradation of herbicides in soil was also reported for tropical regions (Janaki et al., 2010; Chinnusamy et al., 2012).

\section{Atrazine dissipation rate in soil}

Unlike pendimethalin, the dissipation rate of atrazine in kharif maize soil was found to be higher under $\mathrm{CA}$ practices $(\mathrm{ZT}+\mathrm{R}-\mathrm{ZT}, \mathrm{ZT}$ $\mathrm{ZT}+\mathrm{R}$ and $\mathrm{ZT}+\mathrm{R}-\mathrm{ZT}+\mathrm{R})$ than the conventional practices. Atrazine dissipation values on day 15 under CT-CT, CT-ZT, $\mathrm{ZT}+\mathrm{R}-\mathrm{ZT}, \quad \mathrm{ZT}-\mathrm{ZT}+\mathrm{R}$ and $\mathrm{ZT}+\mathrm{R}-\mathrm{ZT}+\mathrm{R}$ practices were observed to be $48,56,63,67$ and 76 percent for atrazine alone application at $0.5 \mathrm{~kg} / \mathrm{ha}$ and 52,56, 50, 60 and 75 percent, respectively for atrazine $0.5 \mathrm{~kg} / \mathrm{ha}+\mathrm{HW}$ at 45 DAS imposed treatments.
Higher rate of atrazine dissipation under CA practices particularly under ZT-R+ZT-R practices could be attributed to its interception by the decomposing crop residues incorporated during both the previous seasons (kharif 2015 and rabi 2015-16) and conversion into non extractable bound residue fraction which would not be released to the soil solution easily. Greater proportion of nonextractable herbicide or herbicide metabolites in reduced tillage or residueamended soils was also reported by Locke and Bryson (1997). Zablotowicz et al., (1998) reported that the physical-chemical mechanisms, such as the sorption of herbicides by lignocelluloses may reduce the effective solution concentration, thereby cutting bioavailability and biodegradation. Further the retention capacity was associated with the lignin fraction of the residues (Khalil, 2018). The previous season grown lignin rich sunflower crop residue would have increased the atrazine interception under CA practices particularly under $\mathrm{ZT}+\mathrm{R}-\mathrm{ZT}+\mathrm{R}$ and corroborates with the report of Dao (1995). The crop residue in conservation tillage systems plays an important role in the environmental dispersion of agricultural chemicals applied in the field (Dao, 1991). Recycled crop residues can be a temporary storage medium for herbicides, altering patterns of chemical dispersion in conservation tillage when compared to conventional practices. Lowder and Weber (1979) reported at least $30 \%$ of the applied atrazine was intercepted by residue. Irrespective of tillage practices and weed management methods, $>80 \%$ of both the herbicides dissipated from the soil on $45^{\text {th }}$ day after application.

\section{Terminal residues of herbicides}

The residues of the studied herbicides in soil, maize and sunflower grain from different plots were analyzed at the time of crop 
harvest. Residues of both the compounds were found below $0.01 \mathrm{mg} / \mathrm{kg}$, at all the tillage management practices and weed control methods and are well below the maximum residue limit (MRL) set by EPA (2012) and FSSAI (2015).

Table.1 Details of treatment imposed in the study

\begin{tabular}{|c|c|c|}
\hline \multicolumn{3}{|c|}{ Main plot (Tillage methods) } \\
\hline & Kharif (Maize) & Rabi (Sunflower) \\
\hline $\mathbf{T}_{1}$ & Conventional tillage (CT) & Conventional tillage (CT) \\
\hline $\mathbf{T}_{2}$ & Conventional tillage (CT) & Zero tillage (ZT) \\
\hline $\mathbf{T}_{3}$ & Zero tillage + Residue $(\mathrm{ZT}+\mathrm{R})$ & Zero tillage (ZT) \\
\hline $\mathbf{T}_{4}$ & Zero tillage (ZT) & Zero tillage + Residue $(\mathrm{ZT}+\mathrm{R})$ \\
\hline $\mathbf{T}_{5}$ & Zero tillage + Residue $(\mathrm{ZT}+\mathrm{R})$ & Zero tillage + Residue $(\mathrm{ZT}+\mathrm{R})$ \\
\hline \multicolumn{3}{|c|}{ Sub plot (Weed management practices) } \\
\hline $\mathbf{W}_{1}$ & PE Atrazine $0.5 \mathrm{~kg} / \mathrm{ha}$ & PE Pendimethalin $1.0 \mathrm{~kg} / \mathrm{ha}$ \\
\hline $\mathbf{W}_{2}$ & $\begin{array}{l}\text { PE Atrazine } 0.5 \mathrm{~kg} \text { a.i./ha }+\mathrm{HW} \text { on } 45 \\
\text { DAS }\end{array}$ & PE Pendimethalin $1.0 \mathrm{~kg}$ a.i./ha $+\mathrm{HW}$ on $45 \mathrm{DAS}$ \\
\hline $\mathbf{W}_{3}$ & Unweeded check & Unweeded check \\
\hline
\end{tabular}

Table.2 Influence of conservation tillage and weed management practices on residues of pendimethalin $(\mathrm{mg} / \mathrm{kg})$ in sunflower $\left(\mathrm{rabi}^{\prime}{ }^{15}\right.$-16) soil under maize -sunflower system

\begin{tabular}{|c|c|c|c|c|c|c|c|c|}
\hline \multirow[t]{2}{*}{ Treatments } & \multicolumn{4}{|c|}{$\mathrm{W}_{1}$ (Pendimethalin $\left.1.0 \mathrm{~kg} / \mathrm{ha}\right)$} & \multicolumn{4}{|c|}{$\begin{array}{c}\left.\mathrm{W}_{2} \text { (Pendimethalin } 1.0 \mathrm{~kg} / \mathrm{ha}\right)+\mathrm{HW} \\
\text { on } 45 \text { DAS })\end{array}$} \\
\hline & 0 day & 15 day & 45 day & Harvest & 0 day & 15 day & 45 day & Harvest \\
\hline $\mathbf{T}_{1}(\mathrm{CT}-\mathrm{CT})$ & $0.459+$ & 0.131 & 0.057 & BDL & 0.461 & 0.181 & 0.065 & BDL \\
\hline $\mathbf{T}_{2}(\mathrm{CT}-\mathrm{ZT})$ & 0.480 & 0.167 & 0.062 & BDL & 0.426 & 0.171 & 0.079 & BDL \\
\hline $\mathbf{T}_{\mathbf{3}}(\mathbf{Z T}+\mathbf{R}-\mathbf{Z T})$ & 0.479 & 0.178 & 0.067 & BDL & 0.423 & 0.190 & 0.080 & BDL \\
\hline $\mathbf{T}_{4}(\mathrm{ZT}-\mathrm{ZT}+\mathrm{R})$ & 0.467 & 0.196 & 0.087 & BDL & 0.471 & 0.202 & 0.087 & BDL \\
\hline $\mathrm{T}_{5}(\mathrm{ZT}+\mathrm{R}-\mathrm{ZT}+\mathrm{R})$ & 0.476 & 0.198 & 0.090 & BDL & 0.482 & 0.215 & 0.098 & BDL \\
\hline
\end{tabular}

Table.3 Influence of conservation tillage and weed management practices on residues of atrazine $(\mathrm{mg} / \mathrm{kg})$ in maize (kharif' 16$)$ under maize -sunflower system

\begin{tabular}{|c|c|c|c|c|c|c|c|c|}
\hline \multirow[t]{2}{*}{ Treatments } & \multicolumn{4}{|c|}{$\mathrm{W}_{1}$ (Atrazine @ $0.5 \mathrm{~kg} / \mathrm{ha}$ ) } & \multicolumn{4}{|c|}{$\begin{array}{c}\mathrm{W}_{2}(\text { Atrazine } 0.5 \mathrm{~kg} / \mathrm{ha}+\mathrm{HW} \text { on } \\
45 \mathrm{DAS})\end{array}$} \\
\hline & 0 day & 15 day & 45 day & Harvest & 0 day & 15 day & 45 day & Harves \\
\hline $\mathrm{T}_{1}(\mathrm{CT}-\mathrm{CT})$ & 0.261 & 0.136 & 0.052 & BDL & 0.293 & 0.141 & 0.054 & BDL \\
\hline $\mathrm{T}_{2}(\mathrm{CT}-\mathrm{ZT})$ & 0.312 & 0.137 & 0.056 & BDL & 0.316 & 0.140 & 0.061 & $\mathrm{BDL}$ \\
\hline $\mathbf{T}_{\mathbf{3}}(\mathrm{ZT}+\mathrm{R}-\mathbf{Z T})$ & 0.236 & 0.087 & 0.041 & BDL & 0.241 & 0.121 & 0.046 & $\mathrm{BDL}$ \\
\hline $\mathbf{T}_{4}(\mathrm{ZT}-\mathrm{ZT}+\mathrm{R})$ & 0.241 & 0.079 & 0.036 & BDL & 0.239 & 0.095 & 0.049 & BDL \\
\hline $\mathbf{T}_{5}(\mathrm{ZT}+\mathrm{R}-\mathrm{ZT}+\mathrm{R})$ & 0.260 & 0.062 & 0.031 & BDL & 0.270 & 0.068 & 0.039 & BDL \\
\hline
\end{tabular}


Int.J.Curr.Microbiol.App.Sci (2020) 9(7): 1375-1388
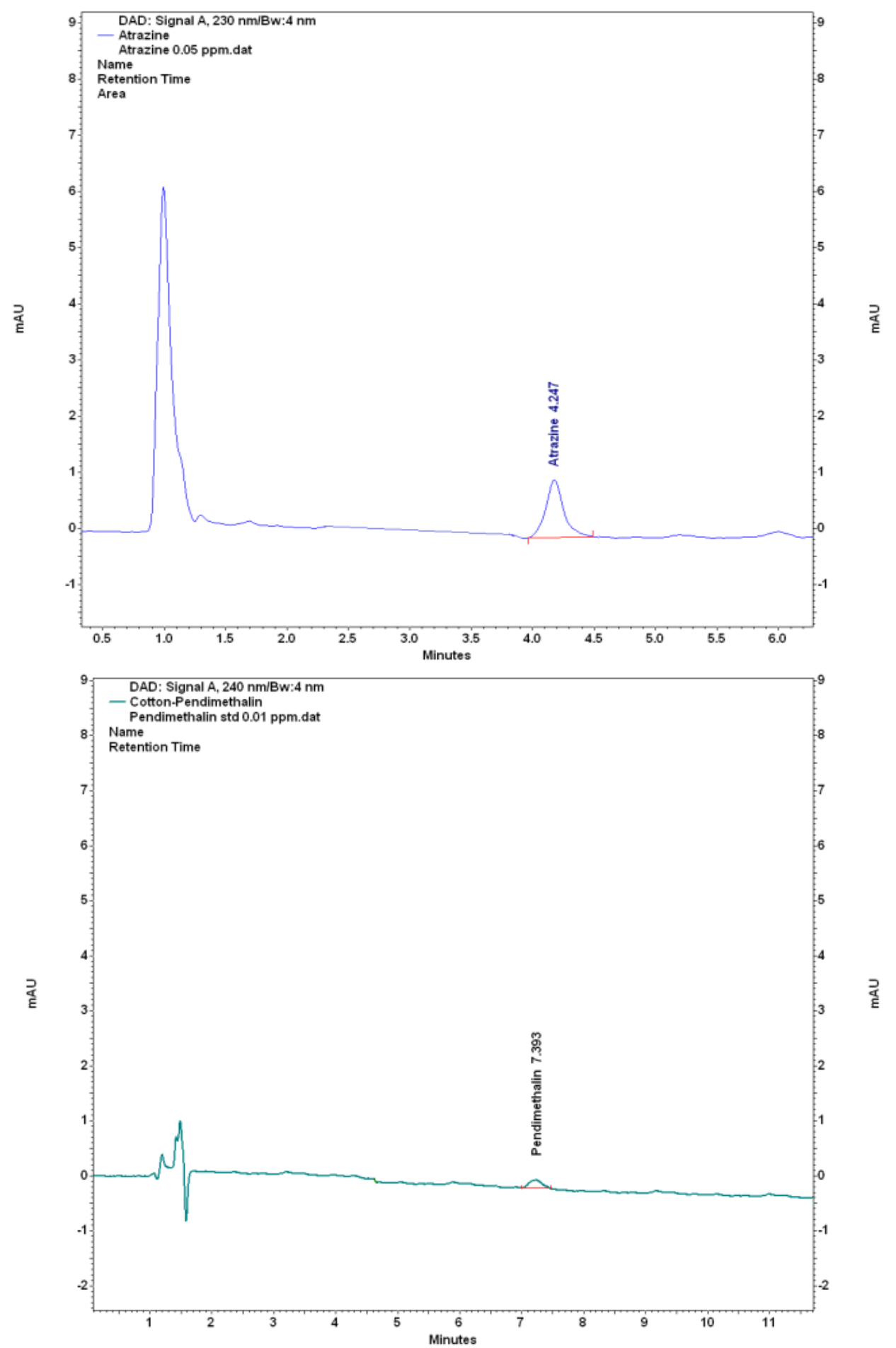

Fig.1 Chromatograms of atrazine $(0.05 \mathrm{mg} / \mathrm{Lit})$ and pendimethalin $(0.01 \mathrm{mg} / \mathrm{Lit})$ standards determined by HPLC 
Int.J.Curr.Microbiol.App.Sci (2020) 9(7): 1375-1388

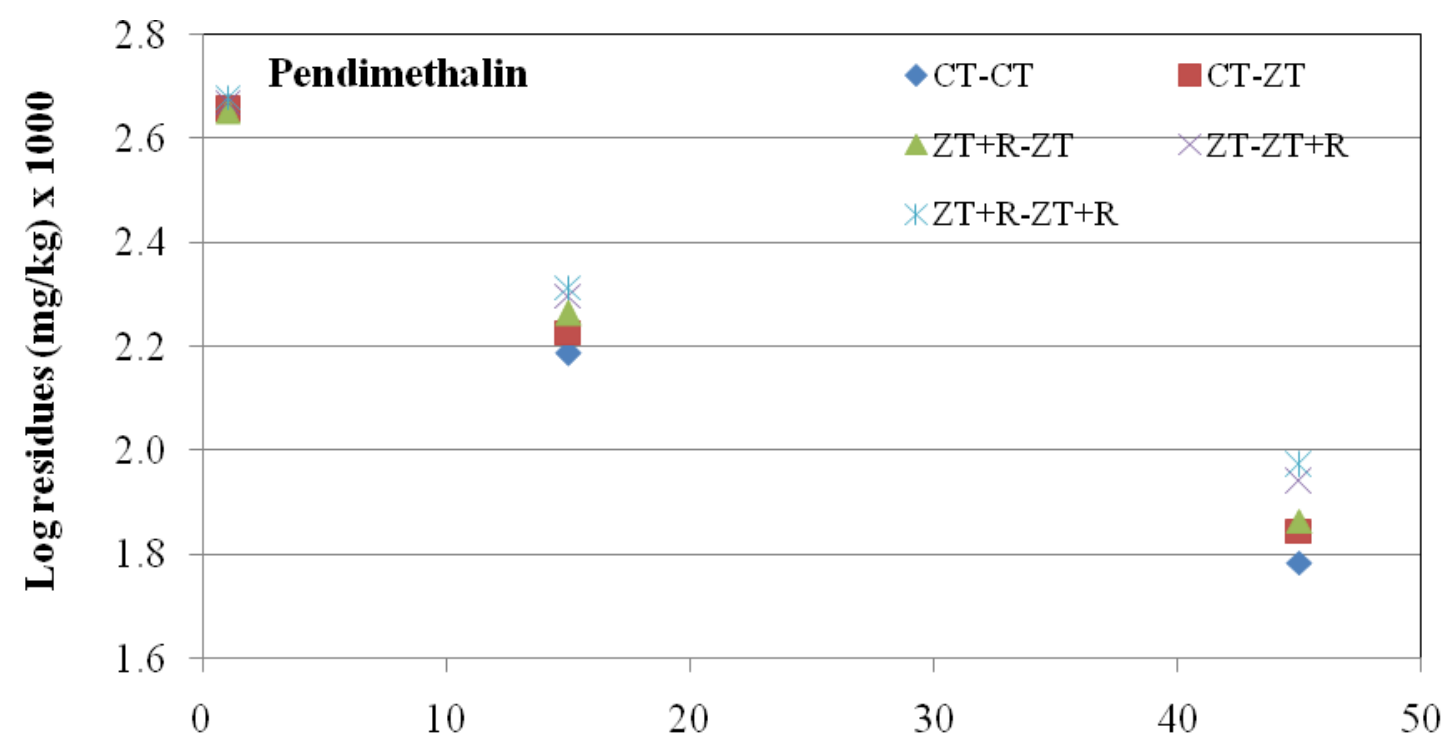

Days after application

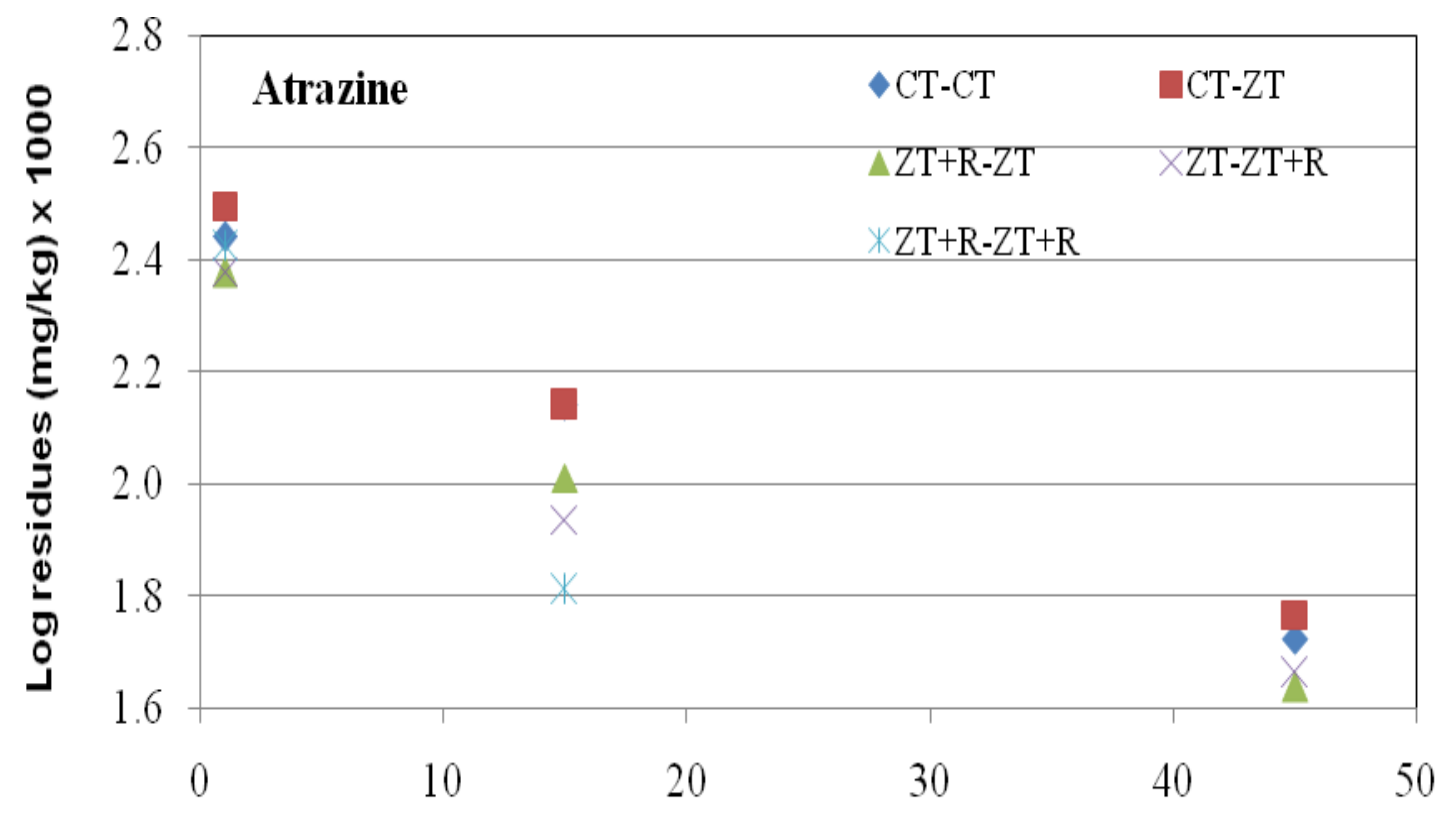

Days after application

Fig.2 Dissipation kinetics of pendimethalin and atrazine from soil under different conservation agricultural practices (CT-Conservation tillage; ZT- Zero tillage; R-Residue incorporation) 
Table.4 Influence of conservation tillage and weed management practices on degradation constant $(\mathrm{k})$ and half life (DT 50$)$ of atrazine and pendimethalin in maize -sunflower system

\begin{tabular}{|c|c|c|c|c|c|c|c|c|c|c|c|c|}
\hline \multirow[t]{3}{*}{ Tillage practices } & \multicolumn{6}{|c|}{ Pendimethalin } & \multicolumn{6}{|c|}{ Atrazine } \\
\hline & \multicolumn{3}{|c|}{$1.0 \mathrm{~kg} / \mathrm{ha}$} & \multicolumn{3}{|c|}{$1.0 \mathrm{~kg} / \mathrm{ha}+\mathrm{HW}$ on $45 \mathrm{DAS}$} & \multicolumn{3}{|c|}{$0.5 \mathrm{~kg} / \mathrm{ha}$} & \multicolumn{3}{|c|}{$0.5 \mathrm{~kg} / \mathrm{ha}+\mathrm{HW}$ on $45 \mathrm{DAS}$} \\
\hline & $\mathrm{k}$ & $\mathrm{DT}_{50}$ & $\mathrm{R}^{2}$ & $\mathrm{k}$ & $\mathrm{DT}_{50}$ & $\mathrm{R}^{2}$ & $\mathrm{k}$ & $\mathrm{DT}_{50}$ & $\mathrm{R}^{2}$ & $\mathrm{k}$ & $\mathrm{DT}_{50}$ & $\mathrm{R}^{2}$ \\
\hline $\mathrm{T}_{1}(\mathrm{CT}-\mathrm{CT})$ & 0.046 & 14.95 & 0.858 & 0.044 & 15.92 & 0.911 & 0.036 & 19.33 & 0.954 & 0.038 & 18.44 & 0.941 \\
\hline $\mathrm{T}_{2}(\mathrm{CT}-\mathrm{ZT})$ & 0.045 & 15.24 & 0.892 & 0.037 & 18.51 & 0.898 & 0.038 & 18.16 & 0.921 & 0.037 & 18.96 & 0.919 \\
\hline $\mathbf{T}_{\mathbf{3}}(\mathrm{ZT}+\mathbf{R}-\mathbf{Z T})$ & 0.044 & 15.86 & 0.900 & 0.037 & 18.73 & 0.923 & 0.039 & 17.82 & 0.884 & 0.037 & 18.83 & 0.948 \\
\hline $\mathbf{T}_{4}(\mathrm{ZT}-\mathrm{ZT}+\mathrm{R})$ & 0.037 & 18.56 & 0.908 & 0.038 & 18.47 & 0.914 & 0.042 & 16.40 & 0.871 & 0.040 & 17.20 & 0.887 \\
\hline $\mathrm{T}_{5}(\mathrm{ZT}+\mathrm{R}-\mathrm{ZT}+\mathrm{R})$ & 0.037 & 18.73 & 0.905 & 0.035 & 19.58 & 0.916 & 0.047 & 14.67 & 0.832 & 0.038 & 18.28 & 0.826 \\
\hline
\end{tabular}

$\mathrm{k}$ - Degradation rate constant $\left(\right.$ days $\left.^{-1}\right) ; \mathrm{DT}_{50^{-}}$Half life (days); $\mathrm{R}^{2}$ - Coefficient of determination.

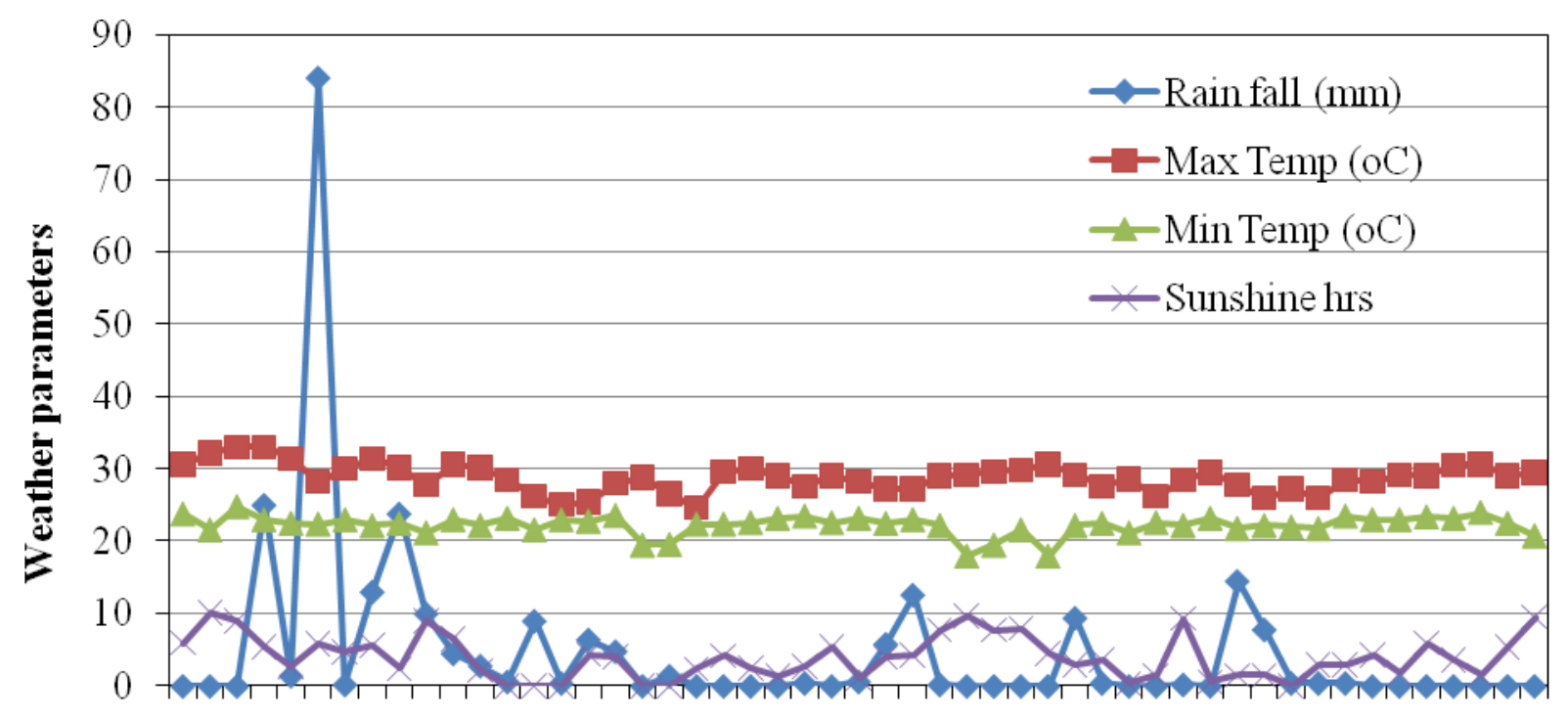

$1 \quad 3 \quad 5 \quad 7 \quad 9111315171921232527293133353739414345474951$

Crop growing period (days after sowing)

Fig 3. Weather parameters recorded during the sunflower crop growing period 


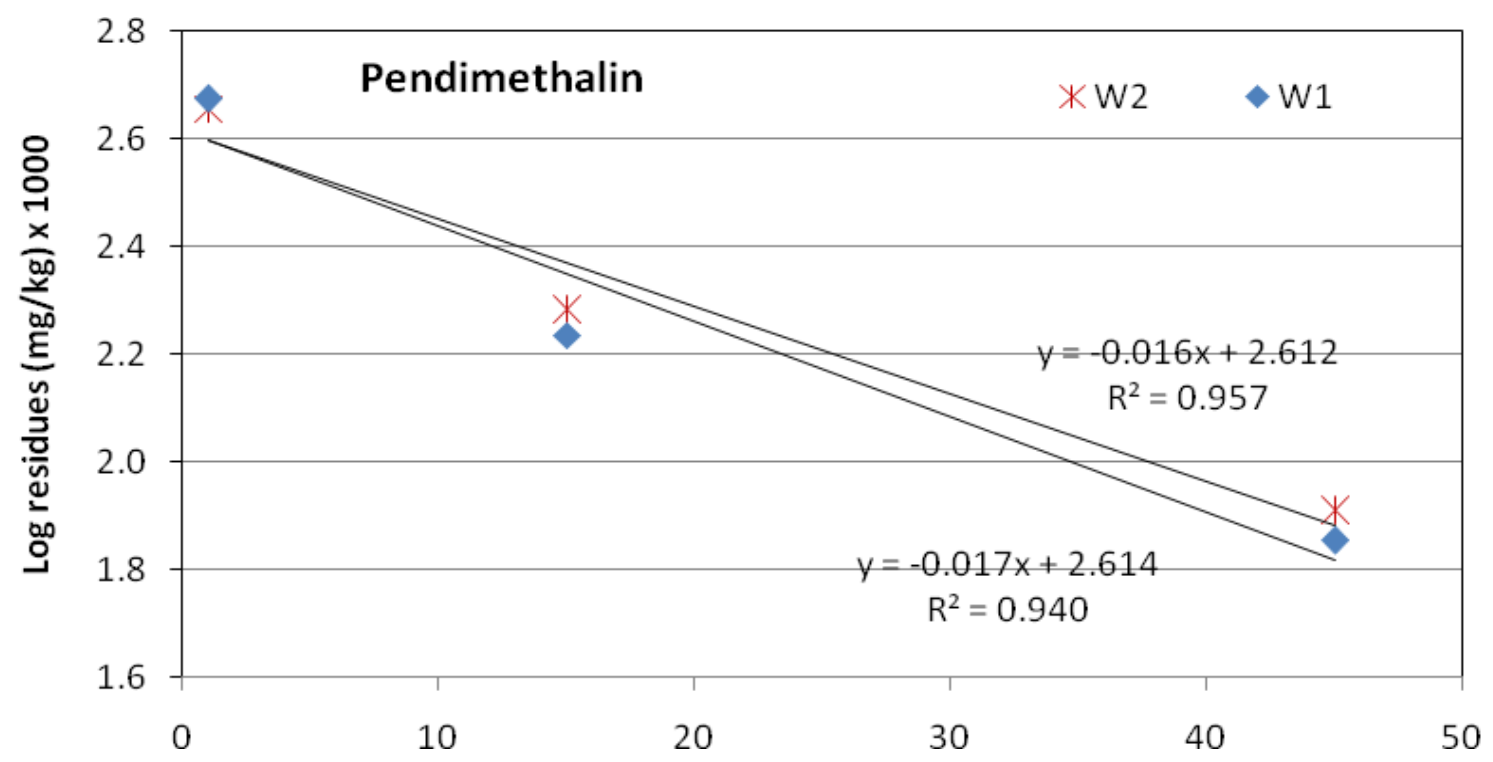

Fig 4. Dissipation kinetics of pendimethalin from soil under two weed management methods (W1- PE Pendimethalin $1.0 \mathrm{~kg} / \mathrm{ha}$ alone; W2- PE Pendimethalin $1.0 \mathrm{~kg} / \mathrm{ha}+\mathrm{HW}$ on $45 \mathrm{DAS}$ ).

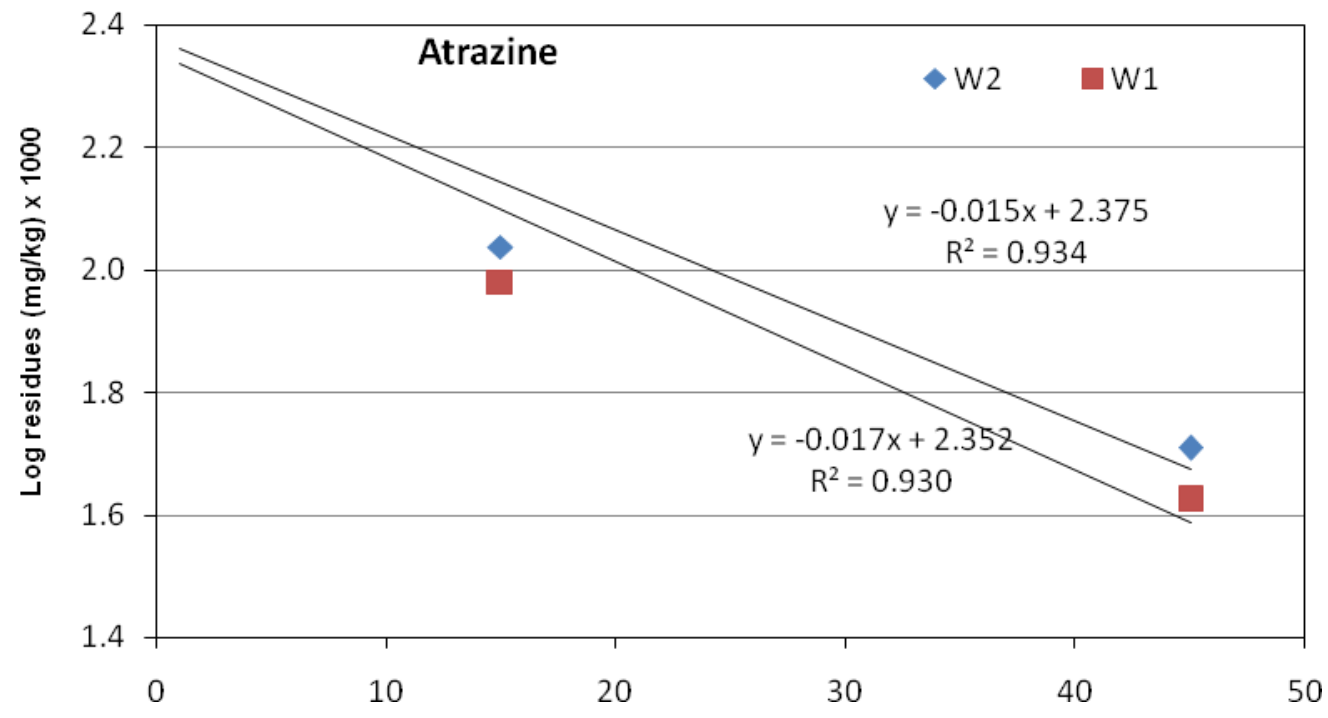

Fig 5. Dissipation kinetics of atrazine from soil under two weed management methods (W1- PE Atrazine $0.5 \mathrm{~kg} / \mathrm{ha}$ alone; W2- PE Atrazine $0.5 \mathrm{~kg} / \mathrm{ha}+\mathrm{HW}$ on $45 \mathrm{DAS}$ )

The residue of pendimethalin in sunflower grain was well below the MRL of $0.05 \mathrm{mg} / \mathrm{kg}$ set by FSSAI (2015) for oilseed crop soybean. The MRL was not set by the FSSAI for atrazine residue in maize and is easily metabolized by the crop into non toxic products (Janaki et al., 2016). Marcacci (2004) reported that the maize have tolerance to atrazine by its conversion into non phytotoxic metabolites through the 
replacement of chlorine atom from the molecule.

In conclusions, results suggests that the influence of CA practices on the persistence of pendimethalin and atrazine is opposite and was influenced by the herbicide nature, its chemistry, crop residue type, tillage type and its continuation besides the climate too. Slow and fast dissipation of pendimethalin and atrazine respectively under zero tillage with crop residue incorporation during the cultivation of both crops in a system showed that the herbicide dissipation behavior is modified by the CA practices. Since the results presented here are for three cropping seasons only, influence of CA practices should be studied under long run to understand the changes in the efficacy and dissipation of herbicides in soil and interactive influence of climatic variables also. Additional research is also essential to recognize the temporal and spatial dynamics of these candidate herbicides in soil under CA systems due to changes in soil physical properties especially water soluble aggregates and preferential water flow and non extractable bound residues formation.

\section{Acknowledgments}

The authors are thankful to the Directorate of Weed Research, Jabalpur and Department of Agronomy, Tamil Nadu Agricultural University, Coimbatore, for providing the necessary research facilities.

\section{References}

Alletto, L, Coquet, Y., Benoit, P., Heddadj, D., and Barriuso, E. 2009. Tillage management effects on pesticide fate in soils. A review. Agron. Sustain. Dev. 30 (2010) 367-400. DOI: 10.1051/agro/2009018.

Anil Kumar, S., and Swaranjit Singh, C.
2013. Adsorption and Desorption Behavior of Chlorotriazine Herbicides in the Agricultural Soils. J Pet. Environ. Biotechnol 4: 154. doi:10.4172/2157-7463.1000154.

Banks, P.A., and Robinson, E.L. 1982. The influence of straw mulch on the soil reception and persistence of metribuzin, Weed Sci. 30: 164- 168.

Chinnusamy, C., Janaki, P., Muthukrishnan, p., and Jeyaraman, S. 2012. Long term herbicidal weed management integrated with nitrogen nutrient in transplanted rice-rice cropping system of Tamil Nadu, India. Pak. J. Weed Sci. Res., Special Issue. 18: 95-103.

Dao, T.H., 1991. Field decay of wheat straw and its effects on metribuzin and Sethyl metribuzin sorption and elution from crop residues, J. Environ. Qual. 20: 203-208.

Dao, T.H., and Lavy, T.L. 1978. Atrazine adsorption on soil as influence by temperature, moisture content and electrolyte concentration, Weed Sci. 26: 303-309.

EPA, 2012. Index to Pesticide Chemical Names, Part 180 Tolerance Information and Food and Feed Commodities. pp 234-236; 2012.

FAO, 2010. Conservation Agriculture and Sustainable Crop Intensification in Lesotho Conservation Agriculture and Sustainable Crop Intensification in Lesotho. Integrated Crop Management Vol.

10-2010. http://www.fao.org/3/i1650e/i1650e00 .pdf.ISBN FAO 2010 978-9-- 2105 6588-4

FSSAI (Food Safety and Standards Authority of India). 2015. Available at:http://old.fssai.gov.in/Portals/0/Pdf/ Draft_WTO_Notification_Pesticides_ 23_11_2015.pdf.

Gaston, L.A., Boquet, D.J., and Bosch, M.A. 2001. Fluometuron wash-off from 
cover crop residues and fate in a loessial soil, Soil Sci. 166: 681-690.

Ghadiri, H., Shea, P.J., Wicks, G.A., and Haderlie, L.C. 1984. Atrazine dissipation in conventional-till and notill sorghum, J. Environ. Qual. 13: 549-552.

Janaki, P., Chinnusamy, C., Meena, S. and Shanmugasundaram, R. 2010. Persistence and degradation behaviour of butachlor and 2, 4-D in rice soil under continuous and rotational use: Effect of nitrogen sources and seasons. In: Proceedings of International Rice Research Conference, 8-12 November, Hanoi, Vietnam, pp. 3817.

Janaki, P., Chinnusamy, C., Sakthivel, N., and Nithya, C. 2015. Field dissipation of pendimethalin and alachlor in sandy clay loam soil and its terminal residues in sunflower (Helianthus annus L.). Journal of Applied and Natural Science 7 (2): 709-713

Janaki, P., Meena, S., and Chinnusamy, C. 2012a. Field Dissipation of Herbicides under Different Crops in Tamil Nadu. Madras Agric. J., 99 (10-12): 794-798

Janaki, P., Meena, S., and Chinnusamy, C. 2009. Persistence and degradation of herbicides in rice, maize and soybean grown Vertisols of Tamil Nadu, Southern India. In: Proceedings of the 2nd International Conference on Novel and Sustainable Weed Management in Arid and Semi-Arid Agro-Ecosystem, 7-10 September 2009, Santorini, Athens, Greece.

Janaki, P., Meena, S., Shanmugasundaram, R., and Chinnusamy, C. 2019. Dissipation and Impact of Herbicides on Soil Properties in Tamil Nadu. In: Sondhia S., Choudhury P., Sharma A. (eds) Herbicide Residue Research in India. Environmental Chemistry for a Sustainable World, vol 12. Springer,
Singapore. doi.org/10.1007/978-98113-1038-6_5.

Janaki, P., S Meena, S., and Chinnusamy, C. , Murali Arthanari, P., and Nalini, K. 2012b. Field Persistence of Repeated Use of Atrazine in Sandy Clay Loam Soil under Maize Madras Agric. J., 99 (7-9): 533-537.

Janaki, P., Sakthivel, N., Prabhakaran, N.K., Chinnusamy, C., and Murali Arthanari, P. 2016. Persistence of atrazine and its management in maize soil by different tillage practices. Clean Up India, 2016. International Conference on Contaminated Site Remediation Proceedings, India, 1315, December, 2016. pp 646-64.

Khalil, Y., Flower, K., Siddique, K.H.M., and Ward, P. 2018. Effect of crop residues on interception and activity of prosulfocarb, pyroxasulfone, and trifluralin. PLOS ONE 13(12): e0208274. https://doi. org/10.1371/journal.pone.0208274

Levanon, D., Meisinger, J.J., Codling, E.E., and Starr, J.L. 1994. Impact of tillage on microbial activity and the fate of pesticides in the upper soil, Water Air Soil Poll. 72: 179-189

Locke, M.A., and Bryson, C.T. 1997. Herbicide-soil interactions in reduced tillage and plant residue management systems. Weed Science, 45:307-320. 1997.

Locke, M.A., and Zablotowicz, R.M. 2003. Pesticides in soil: benefits and limitations to soil quality. In: Schjonning P, Christenson BT, Elmholt S (eds) Managing soil quality. C.A.B.I., Oxon, UK, pp 239-260.

Lowder. S.W., and Weber, J.B. 1979. Atrazine retention by crop residues in reduced tillage systems. Proc. South Weed Sci. Soc. 32: 303-307.

Marcacci, S., 2004. A phytoremediation approach to remove pesticides 
(atrazine and lindane) from contaminated environment, Thesis, Ecole Politechnique de Lausanne.

Nalini, K., Muthukrishnan, P., Chinnusamy, C., and Janaki, P. 2013. Response of soil microflora in herbicide residue of winter irrigated cotton. Crop Res 45(1, $2 \& 3): 268-271$.

Potter, T.L., Truman, C.C., Strickland, T.C., Bosch, D.D., Webster, T.M., Franklin, D.H., and Bednarz, C.W. 2006. Combined effects of constant versus variable intensity simulated rainfall and reduced tillage management on cotton preemergence herbicide runoff, J. Environ. Qual. 35: 1894-1902.

Vencill, W.K., 2002. Herbicide Handbook. 8th edition, Weed Science Society of America, Lawrence, KS, U.S.A. Pp. 1440.

Zablotowicz, R.M., Locke, M.A., and Smeda, R.L. 1998. Degradation of 2, 4-D and fluometuron in cover crop residues. Chemosphere. 37(1):87-101.

\section{How to cite this article:}

Janaki, P. and Murali Arthanari, P. 2020. Effect of Conservation Agricultural Practices on Candidate Herbicides Persistence under Maize-Sunflower System in Tropical Indian Conditions. Int.J.Curr.Microbiol.App.Sci. 9(07): 1375-1388.

doi: https://doi.org/10.20546/ijcmas.2020.907.159 